\title{
NARRAR LA CRISIS
}

Diego Rodríguez ${ }^{1}$

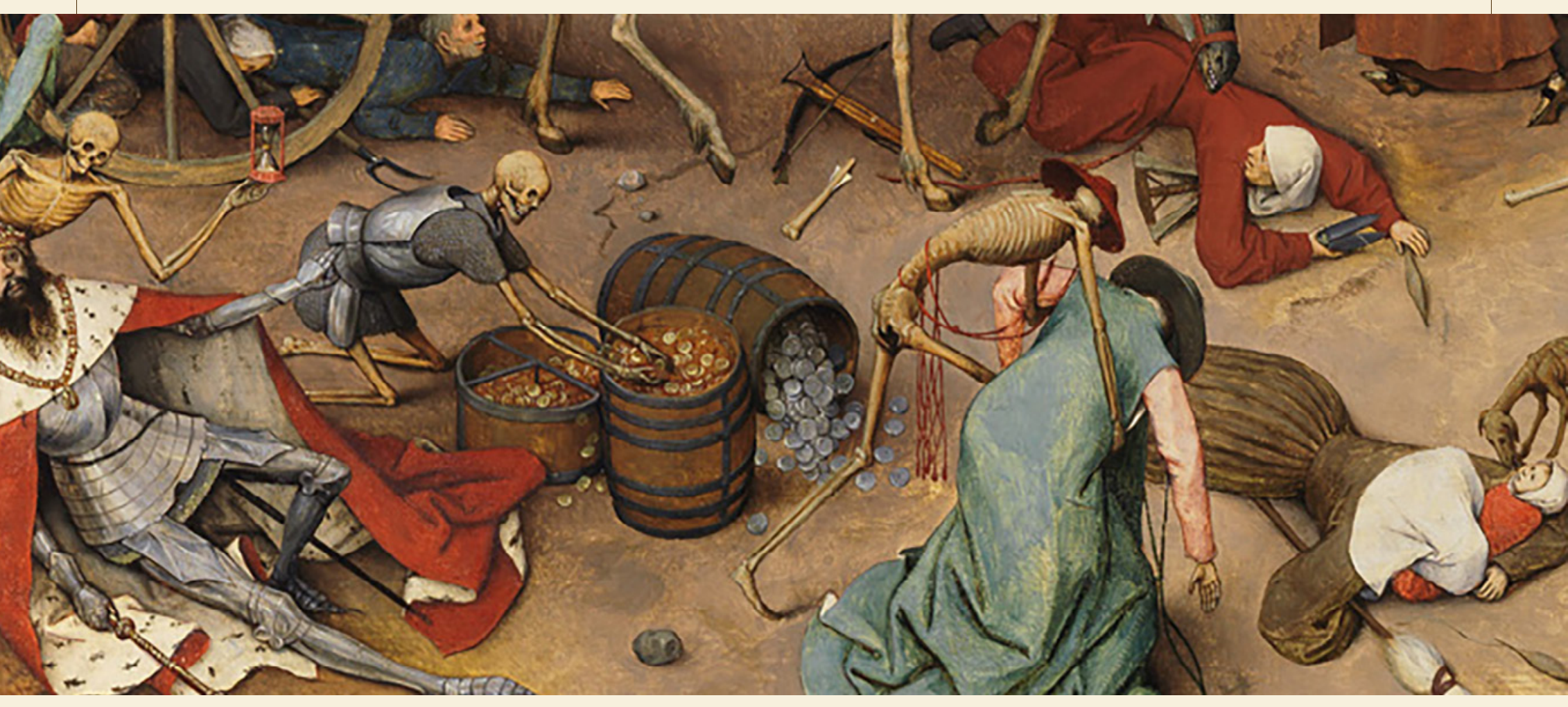

1 Estudiante de la Licenciatura en Humanidades y Lengua Castellana de la Universidad Distrital Francisco José de Caldas. Integrante del semillero de investigación Hermeneia. Correo electrónico: diarodriguezr@correo.udistrital.edu.co ORCID https://orcid.org/0000-0002-5198-5431

Cómo citar: Rodríguez, D. (2020). Narrar la crisis. Enunciación, 25(2, separata), XXXVIII-XLI. https://doi.org/10.14483/22486798.17029 
El Arte es el medio más seguro de aislarse del mundo así como de penetrar en él. Johann Wolfgang von Goethe.

$\mathrm{H}$ ace un par de meses, transcurridas unas semanas de las medidas adoptadas por el Gobierno y otras más de la llegada del desparpajo de salubridad mundial a Colombia, le escribí a un amigo, no tanto con la sincera preocupación que la situación exigía, mas sí con las casi imperativas preguntas de supuesta cortesía con las que se retoma una conversación hace tiempo olvidada. El motivo (o, más bien, el motivante) fue una sugerencia que hizo pública en torno al acercamiento conjunto hacia cierto anime japonés y a los clásicos literarios de este país en los cuales se basaba. Después de pasar por los rodeos de la cortesía y la petición de las referencias literarias, la conversación reflejó un afrontamiento conocido a una realidad siempre cruda e incierta: el consuelo de la palabra.

$\mathrm{Y}$ es que a pesar de que en esta situación la fragmentada conversación escrita pierda el natural afecto con el que surgen las palabras -como si estas llegaran cansadas a su destino y, las mías o las suyas, no bastaran tanto como escuchar el sonido con el que surgen, el contacto que las acoge y el gesto que las alimenta-, creo que el acto mismo de la conversación, del contar, refleja ese consuelo que brinda la palabra como acto de resistencia ante la crisis.

No hay que ir muy lejos en la búsqueda de situaciones donde la palabra fue camino necesario para afrontar problemas, donde su consecución testimonial desahogó corazones, reveló injusticias y permitió observar que su aparición, mediante el primigenio acto de contar lo acontecido, es más que necesaria. Sin embargo, en las crisis actuales, muchos testimonios se ahogan en el mar de la información donde, las imágenes, necesariamente reiterativas, pierden el valor testimonial, dejando en nosotros, sus receptores, un ápice de información y su inmediato olvido. Por eso el recuerdo de la conversación, no tanto por el acto mismo, sino por su temática, donde ante la ausencia del afecto de nuestras palabras, otras fueron las que llegaron a escucharse, que suscitaban el afecto ausente en el distanciamiento, las palabras con las que ambos sorteábamos la ausencia y que llegaban a solventar esa falta de afección de la información cotidiana, ese contacto perene de la palabra literaria.

Recuerdo que en ese momento mi interés se orientaba hacia la literatura que estaba tras el anime recomendado; sin embargo, después de la conversación que, en cierto sentido, destacó la situación actual, debido a los problemas más cercanos de enfrentar la pandemia, hubo un pequeño cambio en cuanto a la reflexión del acercamiento literario, que me permitió recordar el siempre doble valor de la literatura, donde radica tanto la importancia de su creación como el consuelo que brinda su cercanía: el conjunto entre distancia y enfrentamiento respecto de una realidad inmediata, lo que explicaba nuestro interés literario, alejado del problema actual, y nuestra reticencia frente al creciente número de creaciones en torno a la pandemia.

Preferíamos la compañía de Cesar Vallejo, de Fernando Pessoa -y si se acercaba en algo a la realidad actual, de Bocaccio, de Camus o de García Márquez-, que el acercamiento a las creaciones más recientes, obnubiladas por la virulenta propagación informativa, porque estas no llegaban a causar algún afecto. El motivo, si se me permite pensar en solo uno, fue que estas se dejaron ahogar por la exposición de la información. Agotadas de experiencias, las palabras literarias se remitían a lo que la información diaria suministraba, contaban lo ya conocido y sus imágenes, sus metáforas, apuntaban a las mismas volteretas periodísticas que, para el momento, perdían el destino de su llegada y, por tanto, no había un acto sincero de 
afectación, ya que las palabras mismas no surgían como acto terapéutico, sino informativo. En otros términos, la palabra literaria se empeñó en enfrentar la situación actual, sin tomar el irónico distanciamiento que la situación exigía, es decir, si hubo algún distanciamiento, a parte del promovido gubernamentalmente, fue el distanciamiento de lo literario.

Ya antes, en el texto "El narrador", Walter Benjamin (1973) nos advertía del problema que la información le imponía a la narración,

[...] ya no nos alcanza acontecimiento alguno que no esté cargado de explicaciones. [Que] casi nada de lo que acontece beneficia a la narración, y casi todo a la información. [Puesto] que la mitad del arte de narrar radica precisamente, en referir una historia libre de explicaciones. (p. 5)

Esto nos remite, nuevamente, al doble valor de la literatura, que Benjamin sugiere ante la exigencia de distancia y que, en estas ultimas líneas, quiero precisar conjuntamente con su otra cara, siempre problemática $y$, sin embargo, tan necesaria: el enfrentamiento a la realidad, donde se encuentra el consuelo de la palabra, tanto para el escritor como para el lector, en estos tiempos de marcada incertidumbre.

$\mathrm{Al}$ tener esto en cuenta, podría resaltar dos tipos de distanciamiento en la reflexión literaria. El primero es el aparentemente temático, al cual nos remitimos mi amigo y yo ante la ausencia del otro tipo de distanciamiento, el recursivo; en este (el aparentemente temático), descansa el motivo del acercamiento a historias que, aunque distanciadas de la situación actual, reflejan problemáticas inherentes a la condición humana, su finitud, su inacabamiento, su incertidumbre, algo que se redescubre con mucha más profundidad en los momentos de crisis como el que continuamos viviendo.
Por eso es aparente, porque, aunque no refiera directamente a la crisis actual, no se puede afirmar que no tenga relación alguna con ella, pues la relación es con la contingencia, refleja siempre el afrontamiento a una realidad que, a pesar de sus diferentes situaciones y manifestaciones, descubre esa angustia a la cual con pertinencia refería Kierkegaard (1982) como vértigo de la existencia, temor de la libertad.

El segundo tipo de distanciamiento es el recursivo. Con este me refiero al distanciamiento de la información, no tanto a su contenido mismo, pues considero que es un momento necesario en la creación literaria y en la participación política, sino a sus recursos expresivos, a las explicaciones que refiere Benjamin, que hacen que la palabra caduque a cada segundo, al contrario de la siempre actualizada afección que brinda la narración, la literatura, como posible apertura al hermético horizonte de sentido en el cual nos sume una información, por cierto sesgada.

Ambos distanciamientos, tanto el aparentemente temático como el recursivo, implican un afrontamiento directo o indirecto de la realidad, lo que, en esencia, obliga a pensar en un único tipo de distanciamiento ya que el primero, más marcado en imágenes distanciadas de las situaciones inmediatas, es meramente recursivo, nunca indiferente; de ahí, la conjunción con el enfrentamiento. Es decir, el contar literariamente, el narrar, nunca se aleja de forma definitiva de la situación en la que surge, solo toma distancia para enfrentarla, siempre distanciada de los recursos expresivos de la sobreproducción informativa, con el fin de brindar un consuelo terapéutico para el autor, y catártico y hermenéutico para el lector, donde podemos reconocernos en la narración como diferentes, con el fin de comprender las maneras de afrontar las crisis en cada situación, ya que, bien sea distanciada o no, ahí se encuentra la literatura, como diría Juan Gelman (2008), "de pie contra la muerte". 


\section{Referencias}

Benjamin, W. (1973). El narrador. Revista de Occidente, 129, 301-333. Recuperado de http://www.archivochile.com/Ideas_Autores/ benjaminw/esc_frank_benjam0004.pdf

Gelman, J. (23 de abril de 2008). Discurso Premio Cervantes 2017. [Archivo de video]. Recuperado de https://www.rtve.es/ alacarta/videos/premios-cervantes-en-el-archivo-de-rtve/ discurso-juan-gelman-premio-cervantes-2007/2785586/

Kierkegaard, S. (1982). El concepto de la angustia. Madrid: Espasa-Calpe, S. A.

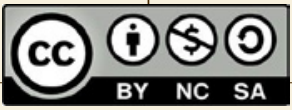

